\title{
The European Union: It's Place in the World Economy and the Impact on the International Economic Processes
}

\author{
Natalia Victorovna Kuznetsova ${ }^{1} \&$ Anna Andreevna Tarabukina ${ }^{1}$ \\ ${ }^{1}$ Far Eastern Federal University, Russia \\ Correspondence: Natalia Victorovna Kuznetsova, Far Eastern Federal University, Building 22 (G), v. Ayaks, 10, \\ Russkii Island, Primorskii Region, 690950, Russia.
}

Received: May 26, 2014 Accepted: June 6, 2014 Online Published: July 29, 2014

doi:10.5539/ass.v10n15p230

URL: http://dx.doi.org/10.5539/ass.v10n15p230

\begin{abstract}
Main goal of the paper is to define the European Union place in world economy and evaluate the impact on international economic processes. The article proves that in spite of the crisis and a sharp national debt problem, Europe doesn't lose its positions. The presence of the highly developed industry, developed system of transnational corporations and banks, manufacturing of the big pat of high technology products, conducting wise policy in the R\&D sphere, and high competitiveness of most of the EU countries in the world economy assured big inflows of investments in the Union economy. This had a positive impact on the level of well-being in the member countries and their social and economic development, which is confirmed by the indicators of income levels per capita and human development. The European Union remains the leading integration block, which is not only competing with the United States, Japan, and China, but also is in the lead of this race. Presence of the highly developed industry, developed system of transnational corporations and banks, production of a large part of high-technology products, and high competitiveness of most of the EU countries are proven statistically. It's demonstrated that the appearance of this market is one of the most significant events in the modern world economy.
\end{abstract}

Keywords: leading countries, inflation, competitiveness, reproduction process, social and economic position

\section{Introduction}

The European Union, which includes 28 countries by the beginning of 2014 with the population of more than 509 million people, is the biggest economic and political integration union in the world and one of the modern world economy leaders. Beginning from the middle of the previous century, the European Union's weight in the world economy has been growing, as its significance as an economically strong center, competing with the U.S., Japan, and China.

By the middle of the XX century Western European economy was destroyed as a result of the World War II: there were a high inflation rate, the lack of the raw materials, energy resources, and food, and national currencies lost their convertibility. So, the industrially developed countries of the Western Europe began to lose their positions at the world arena. Their weight in the GDP of the developed countries reduced sharply, comparing with the weight of North America in 1913-1948 (from 51.8\% to 28\%); the weight of the U.S. increased from $44.2 \%$ to $55.8 \%$ (Shishkov, 2000). To restore and increase economic strength Western European countries took the road of integration of their economies.

In the opinion of A.I. Nikitenko, the EU economic system is a constantly developing single complex with the single reproduction process, which, first of all, is distinguished by structural differences and high differentiation in social and economic position of the EU countries, which will require significant efforts of the Union to eliminate them (Nikitenko, 2009). In the opinion of N. Roubini and N. Berggruen, the EU countries should move towards full integration by expanding the power of the institutions and increasing federalization inside the EU frames, and only this will help strengthen the Union's positions in the modern world economy (Roubini and Bergguen, 2011).

Many economists bring up the question about contradictoriness of the integration in Europe. In the opinion of W. Pfaff, the European Union development happens in an attempt to create "the union" out of "sovereign countries" that leads to big difficulties in taking into account national governments' interests; therefore, he suggests Europe 
following only one direction. The American analyst emphasizes also that the EU is the one subject of the modern that can compete with the U.S. (Pfaff, 1993).

Another American economist F. Bergsten also marks the doubtless potential of the EU, which outshines other world economy leaders (including the USA) in indicators of economic strength and trade flows, and which has a "single voice" in making decisions about large spectrum of economic problems (Bergsten, 1999).

\section{Materials and methods}

Methodology of calculations for estimation of the European Union's place in the world economy includes collection and analysis of statistical data (the World Bank, the United Nations, and Eurostat data in nominal and real values) on the main macroeconomic indicators. The main macroeconomic indicators - dynamics of the EU's GDP weight in regard to the world product and grouping of exports and imports weight are used for estimation of growth of the Union's economy role in the world at different stages of EU's development (1950 - 2012). The comparison of the European Union with the biggest actors of the modern world economy - the USA, Japan, and China, - is made.

The estimation of the attractiveness of the EU countries' economies for foreign investors is made according to the foreign direct investment inflows to the European Union economy. Standard of living is defined by the human development index and income per capita level in all the EU member countries. The data on the intrablock trade are the evidence of the integration processes maturity level within the EU.

\section{Results}

The weight of the initial members of the Union (the six developed countries that were members of the ECSC) in the world gross product before the association was less that $15 \%$. While uniting and enlarging, the EU weight in the world economy, as the significance of the Western European counties, was growing. On the Fig. 1 the data of dynamics of the EU (Community) weight in the world's GDP at the different periods of integration from 1950 to 2012.

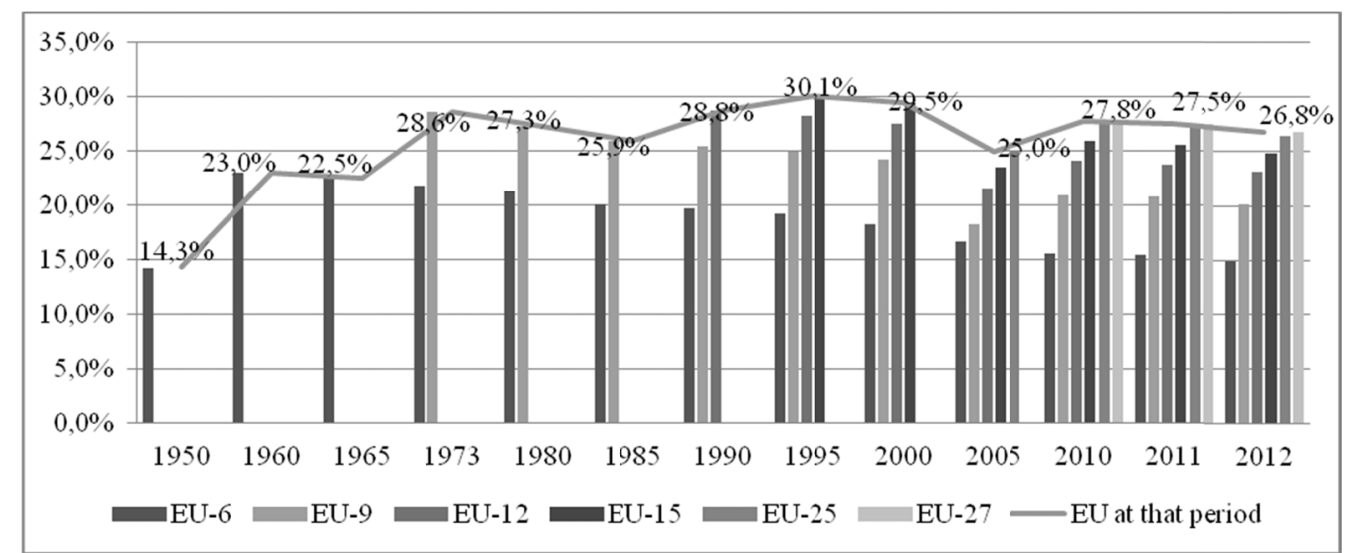

Figure 1. Dynamics of EU weight in the world gross product in 1950-2012 (composed of: World Databank, 2013; The National Accounts Main Aggregates Database, 2013)

Thus, by the beginning of the XXI century, for the EU weight there was almost one third of the world gross product, taking into account that there is a little more than $7 \%$ of the world's population living on the EU territory (The World Factbook, 2013). Besides, GDP of the countries, members of the Union at different periods of its development, has grown by 7 times from 1960 (EU-6) to 2012 (EU-27) (World Databank, 2013).

Considering the European Union against a background of other economically strong actors - the USA, Japan, and China, - it's necessary to note that the main competition for the Western European economy is the United States of America (see Fig. 2).

As we can see, in the beginning of the 70-s the EU weight in the world GDP first exceed the US indicators, and during the next years the Union had a bigger weight almost always.

In percent proportion of the nominal value, the gap between the USA and the EU is only $0.5 \%$, but in the monetary expression this indicator is more that 383 billion dollars to the European Union. At the same time, the Eurozone (17 industrially developed countries) weight in the EU GDP was more than 12 trillion dollars in 2012 (73\%) (World Databank, 2013). 


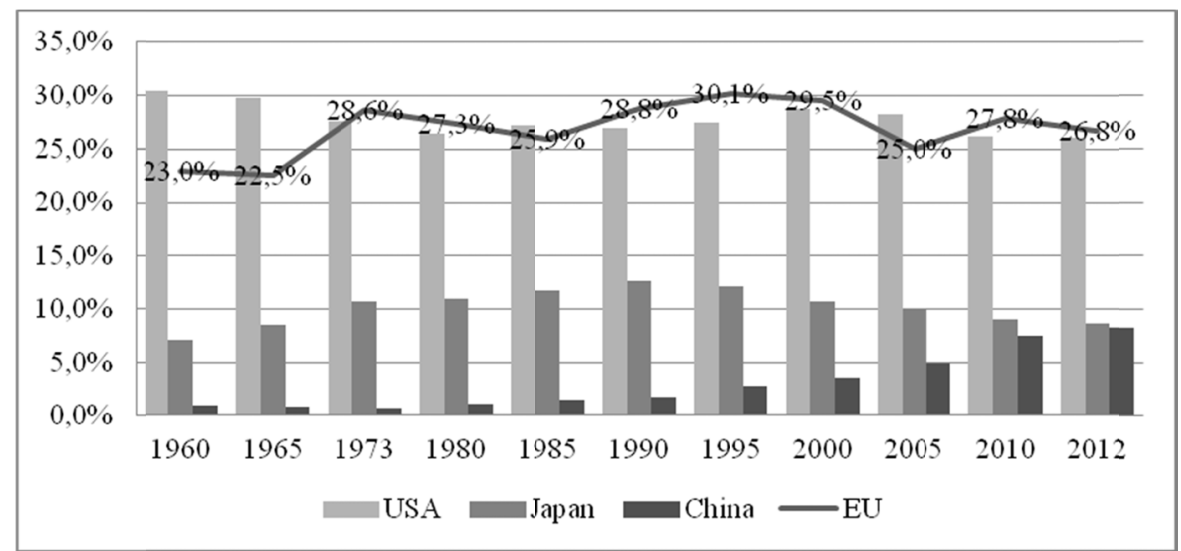

Figure 2. Dynamics of the weights of the EU, the USA, Japan, and China in the world gross product (1960-2012) (composed of: World Databank, 2013)

Free trade between the member countries inside the Union has increased the goods and services turnover significantly. Overall the exports and imports of goods and services of the Western European countries for the last two decades have grown by more than 3.5 times.

It can be noticed that both exports and imports of the EU make up about one third of the world's indicators. Concerning its GDP, exports and imports made up 43\% and 41\% respectively in 2012 .

Comparison of the EU with the United States, Japan, and China in the exports and imports values is to the European Union unconditionally (see Table 1).

Table 1. Imports and exports of the EU, the USA, Japan, and China in comparison with the world's indicators, in millions of dollars (1990-2012) (World Databank, 2013)

\begin{tabular}{cllclll}
\hline Indicator/Country & \multicolumn{1}{c}{1990} & 1995 & \multicolumn{1}{c}{2000} & \multicolumn{1}{c}{2005} & \multicolumn{1}{c}{2010} & \multicolumn{1}{c}{2012} \\
\hline World & 4411423 & 6329443 & 7991565 & 12842587 & 18475182 & 22077522 \\
The EU & 1979819 & 2585035 & 3037014 & 5047210 & 6490238 & 7152427 \\
The USA & 629700 & 902600 & 1474400 & 2026100 & 2362000 & 2743100 \\
Japan & 291102 & 410559 & 446089 & 589997 & 768047 & 992054 \\
China & 46706 & 135282 & 250688 & 712090 & 1520365 & 2016526 \\
\hline & & \multicolumn{7}{c}{ Exports } \\
World & 4350175 & 6469327 & 7996821 & 12992073 & 18971306 & 22629160 \\
The EU & 1943185 & 2728053 & 3055599 & 5149505 & 6642896 & 7467765 \\
The USA & 551900 & 812800 & 1094300 & 1310400 & 1843500 & 2195900 \\
Japan & 319309 & 482858 & 514630 & 654357 & 833704 & 873964 \\
China & 57374 & 147240 & 279561 & 836888 & 1743367 & 2248377 \\
\hline
\end{tabular}

In 2012 European Union made up 32\% of the world's imports and 33\% of the world's exports, while the same indicators for the USA were $12 \%$ и $9.7 \%$, for Japan $4.5 \%$ and $3.9 \%$, and for China $9.1 \%$ and $9.9 \%$ respectively. At the same time, most EU member countries are the industrially developed countries, therefore, the biggest part of their GDP makes up tertiary sector - services (72.87\%) (The World Factbook, 2013).

Important indicator of having trust in a country's economy (in our case, a group of countries) is foreign direct investments. In the history of the European Union building, the most successful in the foreign direct investment inflow was 2000 (more that $7.5 \%$ of GDP). Then this indicator decreased to $1.7 \%$ in 2004 , increased again in 2005-2008, but next years it fell to $1.9 \%$ in 2010 and $1.8 \%$ in 2012, which was caused by the crisis. However, this indicator for the US was 1.3\% of GDP in 2012 (World Databank, 2013). 
In the international economic relations sphere, one of the main forms of which is creating and developing transnational corporations and financial institutions, the European Union takes also one of the leading positions. In 2012, twelve out of 50 biggest transnational corporations and banks, by Forbes version, are based in the EU member countries (second place after the US), main of which are the UK, Netherlands, Germany, France, Italy, Spain, and Belgium (DeCarlo, 2013).

One of the main indicators of the country development is competitiveness. According to the competitiveness rating composed by the World Economic Forum, most of the EU countries take first positions.

All the EU members take one of the top one hundred positions with the biggest scores of competitiveness. Finland, Germany, Sweden, Netherlands, and the UK are at the first ten positions there. The least competitive country of the EU out of the 28 members is Greece (rank 91), which is connected to the debt crisis that has spread out the Eurozone since 2010, and low economic development indicators at the moment of entering the EU. For comparison, USA has the fifth position, Japan is at the ninth, and China is $29^{\text {th }}$ (World Economic Forum, 2013).

One of such indicators of social and economic development level is a human development index, which was suggested by the UN. It reflects life expectancy at birth, the educational level, and income level per capita. In 2012, 26 out of $28 \mathrm{EU}$ member countries have classification as countries with a very high human development index and take one of the top fifty positions. Only two countries - Romania and Bulgaria - have a "high" HDI $\left(0.786\right.$ and 0.782 respectively) and take $56^{\text {th }}$ and $57^{\text {th }}$ positions in the rating. First positions belong to Netherlands, Germany, Ireland, and Sweden.

This index allows to ascertain a high level of well-being in the EU countries, and in the Eurozone countries, as well (see Fig. 3).

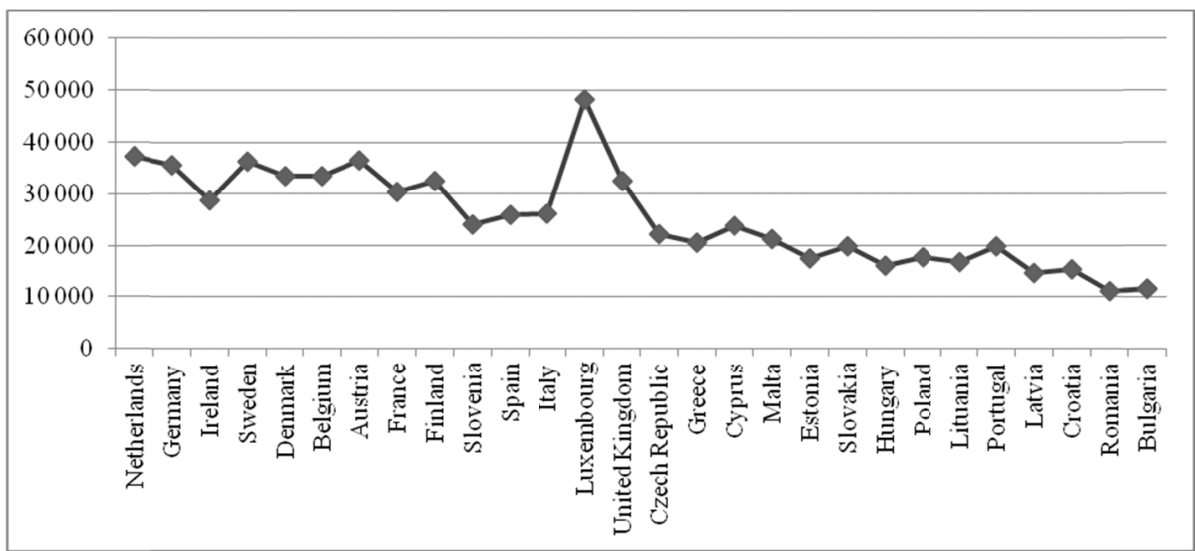

Figure 3. GNI per capita, PPP (US dollars), 2012 (composed of: Human Development Report, 2012)

Taking into account that the average GNI per capita in the world is 12186 dollars, we see that all the European Union (and Eurozone) countries, except Romania and Bulgaria, have bigger figures. The leader in GNI per capita value among the EU countries is Luxembourg. Moreover, the average GNI per capita in the EU in 2012 (33 527 dollars) is higher than the average GNI in the world in 2.75 times, and the same indicator in the Eurozone (36 217 dollars) is higher in almost 3 times (World Databank, 2013).

From all the integration blocks, the EU is the most economically powerful. Among such big blocks as NAFTA, ASEAN, MERCOSUR, and the Customs Union, the EU has the biggest weight of trade between member countries (60\%), which indicates a very high level of integration (see Fig. 4).

The EU maintains diplomatic relations with more than 130 countries. EU holds the major part of the help for developing countries: according to the Lome conventions, the EU has agreements about association with 69 countries of Africa, the Caribbean and Pacific group of States, and bilateral treaties with other 60 countries (The Lome Convention, 2013).

Public debt of all the $27 \mathrm{EU}$ countries in 2011 increased by $2.8 \%$ in comparison with the previous year figures (from $82.5 \%$ of GDP to $85.3 \%$ ), and in 2012 it reached the record $90.6 \%$ of GDP. During the last three years, 14 out of $27 \mathrm{EU}$ countries have public debt more than $60 \%$ of the national GDP. The leader in this indicator is Greece (156.9\%) (Public debt of the Eurozone, 2014). 


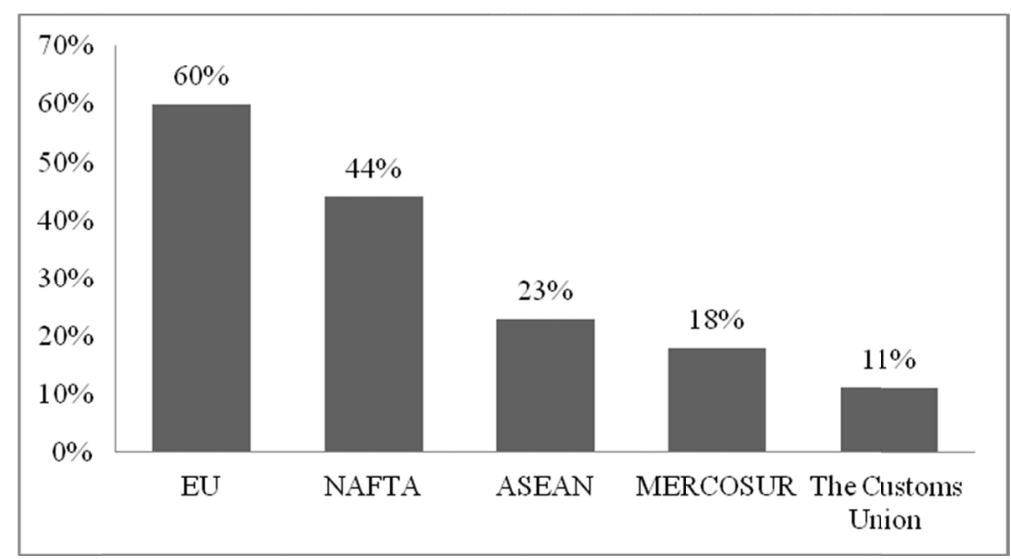

Figure 4. The weight of the intrablock trade in EU, NAFTA, ASEAN, MERCOSUR, and the Customs Union (2011) ([composed of: About the effectiveness, 2013; Use of the common customs, 2013)

However, in spite of the economic breakdown by more than 7\% in 2012, Greece achieved the sharp decrease of the debt in comparison with 2011 figures (170.3\% of GDP). It's followed by Italy (127\%), Portugal (123.6\%), Ireland (117.6\%), Belgium (99.6\%), France (90.2\%), the UK (90\%), Cyprus (85.8\%), Spain (84.2\%), Germany (81.9\%), Hungary (79.2\%), Austria (73.4\%), Malta (72.1\%), and Netherlands (71.2\%). Only six out of 27 EU countries showed tendency to public dept reducing. Countries that owe the least in the percent values are Estonia (10.1\% of GDP), Bulgaria (18.5\%), and Luxembourg (20.8\%).

\section{Discussion}

In Y.V. Shishkov's opinion, the European Union is not only one of the three centers of economic power, having huge influence on the world economy, but it's, first of all, a successful example of real integration of the independent in the past countries, which has become possible due to the enough level of the integration maturity, including the high level of technical and economic development, diversification of production and exports, and openness of the economy (Shishkov, 2000). V.N. Zuev in his works also notes the uniqueness of the eurointegration processes and emphasizes the most typical trait for them, that distinguishes the EU from the other intergovernmental structures, - the supranational mechanism (Zuev, 2011).

S. Medvek considers the EU as a mixture of different in their development economies, emphasizing an important role of the active cooperation of the states within the union in their future success and development of the effective supranational mechanism (Medvec, 2009). A. Wiener and T. Dies bring up the topic of federalization in the eurointegration processes, but also consider the active territory expansion of the EU, advocating it and pointing out to objectivity and regularity of these processes (Wiener \& Dias, 2004).

Certainly, the further study of the specific factors the European Union's influence on world development can give a new impetus to the development of a more rational understanding of integration associations.

\section{Conclusion}

It should be noticed that due to Euro market development the new international financial centers appeared (Luxembourg, Singapore, Hong Kong, Panama, Bahamas and others); in the whole, there are 35 centers of euro currency markets, which leaders are London, Frankfort on the Main, Paris, Zurich-Geneva, Luxembourg, and euro makes up the main competition to the US dollar, as it was supposed to.

Thereby, the appearance of this market is one of the most significant events in the modern world economy. During the development phases and its enlargement, the European Union increased its economic strength rapidly among the other most developed countries and country groups in the world. By the beginning of the XXI century, the EU took the leading positions in gross product indicators, making more than a third of the world's gross product, and trade turnover indicators not only inside the Union, but also in trade with the third countries. In spite of the crisis and a sharp public debt problem, Europe doesn't lose its significant positions, and some countries, on the contrary, show positive statistics.

\section{References}

About the effectiveness of the Customs Union functioning at the current period. "Da Vinci AG" Analytic Group (2013). Retrieved December 20, 2013, from http://www.davinci.org.ua/docs/CU140313.pdf 
Bergsten, F. (1999). America and Europe: Clash of the Titans. Foreign Affairs, 78, 20-34. http://dx.doi.org/10.2307/20049206

DeCarlo. S. (2013, April 17). The World's Biggest Public Companies. Forbes. Retrieved May 2, 2013, from www.forbes.com/global2000/\#page:5_sort:0_direction:asc_search:_filter:All\%20industries_filter:All\%20co untries_filter:All\%20states

Human Development Report. (2012). United Nations Development Program (p. 216).

Medvec, S. (2009). The European Union and expansion to the East: Aspects of accession, problems, and prospects for the future. International Social Science Review, 84, 66-83.

Nikitenko, A. I. (2009). European Union: problems of internal integration. Central Russian Bulletin of Social Sciences, 2, 180-184.

Pfaff, W. (1993). Is Liberal internationalism dead? World Policy Journal, 10, 5-13.

Public debt of the Eurozone broke the record. Interfax. (2013). Retrieved February 13, 2014, from www.interfax.ru/business/txt.asp?id=303066

Roubini, N., \& Bergguen, N. (2011). Only Full Integration Can Save Europe. NPQ: New Perspectives Quarterly, 28, 14-16. http://dx.doi.org/10.1111/j.1540-5842.2011.01278.x

Shishkov, Y. V. (2000). The place and the role of the European Union in the modern world. Relevant Problems of Europe, 3, 11-29.

The Forbes. World Economic Forum. (2013, September 4). The Global Competitiveness Index 2014 rankings. Retrieved November 12, 2013, from http://www3.weforum.org/docs/WEF_GlobalCompetitivenessReport_ 2013-14.pdf

The Lome Convention. (2013). Background. Retrieved December 12, 2013, from www.homepages.uel.ac.uk/ mye0278s/ACP1.htmhtm

The National Accounts Main Aggregates Database. (2013). The United Nations Statistics Division. Retrieved November 12, 2013, from http://unstats.un.org/unsd/snaama/selbasicFast.asp

The World Factbook. (2013). The Central Intelligence Agency. Retrieved November 14, 2013, from https://www.cia.gov/library/publications/the-world-factbook/index.html

Use of the common customs tariff in the European Union countries. (2013). The Customs Broker. Retrieved December 23, 2013, from www.brokert.ru/material/primenenie-tamozhennogo-tarifa-evropeyskiy-soyuz

Wiener, A., \& Dias, T. (2004). European Integration Theory. Oxford University Press (p. 296).

World Databank. (2013). The World Bank. Retrieved December 12, 2013, from http://data.worldbank.org/ country

Zuev, V. N. (2011). Supranational mechanism - the main instrument of the European integration? Modern Europe, 2, 94-108.

\section{Copyrights}

Copyright for this article is retained by the author(s), with first publication rights granted to the journal.

This is an open-access article distributed under the terms and conditions of the Creative Commons Attribution license (http://creativecommons.org/licenses/by/3.0/). 